\title{
The Effectiveness of Turtle Mobile Learning Application for Scientific Literacy in Elementary School
}

\section{Endang Widi WINARNI ${ }^{1}$ (D) Endina Putri PURWANDARI ${ }^{2}$}

'Lecturer, Elementary Education Department, Faculty of Teacher Training and Education, University of Bengkulu, Bengkulu, Indonesia.

Email:endangrwidi@unib.ac.id

${ }^{2}$ Lecturer, Information System Department, Faculty of Engineering, University of Bengkulu, Bengkulu, Indonesia. Email:endinaputri@unib.ac.id

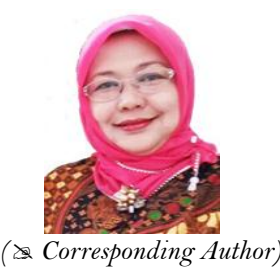

\section{Abstract}

Turtles are animals vulnerable to extinction. Scientific literacy is the main goal of the science curriculum. Augmented Reality technology is very helpful in the education process of animal conservation. Turtle mobile learning is one of the scientific literacy sources developed on Android smartphones. The study's purpose is to produce and determine the effectiveness of turtle mobile learning media to develop the students' scientific literacy about Sumatran turtle conservation. The study used Research and Development (R \& D) design and One Group Pretest Posttest design. The research participants were elementary school students in Bengkulu City. Based on the pretest and posttest results, the value of $t=0.975$ for a two-tailed test on the distribution of student $(t) d_{k}$ $=38$ obtained $\mathrm{t}$-table $=2.024$ from the calculation $\mathrm{t}=-10.71$ located in the reject area of null hypothesis. It concluded that there is an influence on aspects of student understanding about Sumatran turtles. The $\mathrm{N}$-gain results calculation analysis was about 0.8, indicating that this application has high effectiveness in improving the scientific literacy of elementary school students. The experiment showed that students could understand the lesson easily and acquire improved motivation to seek new concepts. This is because turtle mobile learning with augmented reality technology provides students with convenience in building concepts and simplifying the turtle visualization.

Keywords: Scientific literacy, Sumatran turtle, Augmented reality, Mobile learning, Elementary school, Learning media, Research and development.

Citation $\mid$ Endang Widi WINARNI; Endina Putri PURWANDARI (2019). The Effectiveness of Turtle Mobile Learning Application for Scientific Literacy in Elementary School. Journal of Education and e-Learning Research, 6(4): 156-161.

History:

Received: 2 September 2019

Revised: 4 October 2019

Accepted: 6 November 2019

Published: 25 Nover 2019

Lublished: 25 Novis 2019

Attribution 3.0 License $(\mathrm{cc})$

Publisher: Asian Online Journal Publishing Group
Acknowledgement: Both authors contributed to the conception and design of the study.

Funding: Authors wish to thank the Directorate of Higher Education, Ministry of Research, Technology, and Higher Education, the Republic of Indonesia, for the research grant.

Competing Interests: The authors declare that they have no conflict of interests.

Transparency: The authors confirm that the manuscript is an honest, accurate, and transparent account of the study was reported; that no vital accurate, and transparent account of the study was reported; that no vital
features of the study have been omitted; and that any discrepancies from the features of the study have been omitted;
study as planned have been explained. study as planned have been explained.
Ethical: This study follows all ethical practices during writing.

\section{Contents}

1. Introduction

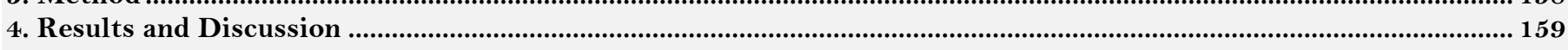

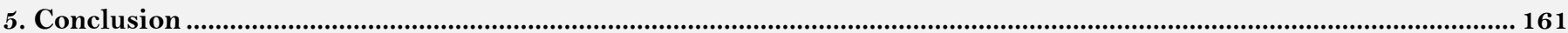

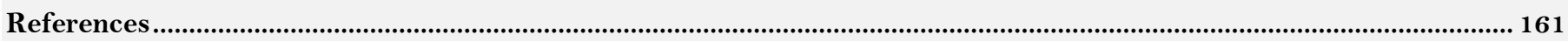




\section{Contribution of this paper to the literature}

This study contributes to the existing literature by providing a new technology for scientific literacy and turtle learning using integrating augmented reality in smartphones as learning media. This study also highlights that turtle mobile learning with augmented reality technology can help the $3 \mathrm{D}$ turtle visualization by students and improve the turtle conservation concept and its understanding by students.

\section{Introduction}

The implementation of literacy programs in a balanced and comprehensive manner is difficult because it is necessary to take account of the individual capabilities of each student. Further, a relevant learning approach is also needed, in this case the value clarification approach with various media technologies. Scientific literacy is the main purpose of teaching science (Aikenhead, 1990). Individual studies can aid in the understanding of the core concepts and principles of science, the correlation between science and humanities, and above all between science and technology (Hodson, 2003). Elementary school students should be imbued with a positive attitude towards science (Cibir and Ozden, 2017).

Science is one of the subjects that occupy an important role in elementary education because science can be an important tool for students facing various challenges in the global era. Scientific literacy is the ability to understand and communicate science, and to apply scientific principles to solve problems (Rusilowati et al., 2016). The Program for International Student Assessment (PISA) found that the scientific literacy of Indonesian students are still below the international average. In 2015, Indonesia was ranked 64th out of 72 participating countries by the Organization for Economic Co-operation and Development (OECD) with a score of 403.

Turtles are vulnerable to extinction because of their very slow growth. They exist in relatively small numbers in a large area so that the possibility of finding a mate is quite low. Also, small turtles only lay around two-to-four eggs in one month. The protection of these animals is very important because of the number of populations that are endangered.

Augmented Reality (AR) is the combination of real and virtual objects in a real environment. It runs interactively in real-time, and integrates objects across three dimensions. Augmented Reality requires a minimum number of components, typically input and output devices, a tracker, and a computer. Augmented Reality technology is very helpful in the education process of animal conservation, especially with the support of markers that allows combining $2 \mathrm{D}$ books as markers that are used to bring up $3 \mathrm{D}$ objects.

Several experts have developed the learning media using Android smartphones. Ambusaidi et al. (2018) purposes virtual labs to improve $9^{\text {th }}$-grade students' achievement. The research showed a positive impact on students who learn with virtual laboratory applications. Android-based learning media with local content can improve the competence of diagrammatic and argumentative representation in physics learning (Liliarti and Kuswanto, 2018). Winarni and Purwandari (2018) developed a mobile educational application that can improve the understanding of disaster preparedness for elementary school students. Subali et al. (2019) developed the scientific learning method for Natural Science in elementary schools. The experiments indicate greater difficulty in the scientific method for students in Grades 4 to 6 than Grades 1 to 3. Furthermore, Wijayanti and Basyar (2016) have suggested the creation of an integrated e-portfolio media web blog based on elementary teacher education program students. The research found that the web blog based thematic integrated e-portfolio media improved the scientific literacy of students in teacher education programs enabling them to fully reach their conceptual abilities in a multidimensional level. Turtles are a treasure of native Indonesian biodiversity (Bappenas, 2016). Indonesian turtles consist of 29 species and are spread relatively evenly across western Indonesia. Indonesia also has various types of turtles whose distribution area is very limited. The research was taken from Science Turtle Conservation in the Learning Resources for Life Sciences at the University of Bengkulu. The types of Sumatran Turtles built in this Augmented Reality application are: (1) Pineapple/thorn/sun turtle (Heosemys spinosa); (2) Black Leaf/Line turtle (Cyclemys odhamii); (3) Broken/turtle (Coura amboinensis); (4) Flat Shell turtle (Notochelys platynota); (5) Brown Baning turtle (Manouria emys); (6) White Cheek turtle (Siebenrockiella crassiocollis); and (7) Ivory turtle (Orthilia borneensis). The study's purpose is to produce and determine the effectiveness of turtle mobile learning media to develop the students' scientific literacy about Sumatran turtle conservation. Scientific literacy brings problemsolving, because people try to solve the problem with their scientific knowledge and ways of thinking. Students must improve their understanding, and gain the opportunity to read, write and defend their thinking in an insightful manner.

\section{Scientific Literacy}

Digital literacy refers to the skills, knowledge, and understanding required to access, use and produce multimodal texts that are disseminated through electronic media, such as computers, consoles, mobile phones, and touch screen technologies (Spante et al., 2018). This is referred to as "new literacy" or "literacy for the digital age". The specific skills associated with this form of literacy deserve separate consideration and do not form part of this resource. One requirement associated with the preservice teachers' science lessons which connected literature and literacy strategies was the task of reflecting upon the lessons using a prescribed set of questions (Nesmith et al., 2017). These questions focused the preservice teachers on various elements regarding the planning and presentation of the literature and literacy strategy instruction, namely: (a) What piece of literature did you use within the science lesson; (b) If you incorporated literacy strategy instruction, what strategy instruction did you utilize, and why was this a good choice; (c) If you incorporated literacy strategy instruction, how did you incorporate the strategy, and why was this a good choice; and (d) If you did not incorporate literacy strategy instruction within your lesson, why did you make this choice, and why do you believe this was a good choice. All of the preservice teachers prepared and submitted the required reflections (Nesmith et al., 2017). Scientific literacy is the ability to use scientific knowledge, identify questions, and draw conclusions based on evidence, and to understand and make decisions regarding nature and the changes made to nature through human activities 
(OECD, 2013). Science literacy, according to PISA, is defined as "the capacity to use scientific knowledge, to identify questions and to draw evidence-based conclusions to understand and help make decisions about the natural world and the changes made to it through human activity." Assessment of scientific literacy is assessing students' understanding of science content, science processes, and the context of science applications. Assessment of scientific literacy is not only oriented to mastering science material, but also to mastering life skills, thinking skills, and the ability to apply science in "real life" contexts (Rusilowati et al., 2016).

\section{Method}

The study used a Research and Development ( R \& D) design. Twenty students were selected by stratified random sampling technique from grads 4 and 5 at elementary school in Bengkulu City during the academic year 2017/2018. The scientific literacy data was gathered from both pretest and posttest. There were three main steps: (1) Research and information collection; (2) Product development; and (3) Dissemination and distribution. In the first stage we defined the curriculum and study material analysis, collected information about the Sumatra Turtle, and undertook science concept analysis and scientific literacy analysis. The second stage aimed to create the model or instrument software based on information and analysis from the first stage. In this stage, we developed the mobile learning media for Sumatra turtle education as a scientific literacy source that runs on Android smartphones. The processes of the application production were storyboard design, interface design, drawing the turtle, and converting it into the augmented reality model. In the final stage we disseminated and distributed the turtle mobile learning by uploading the application to the Google Play store. The application's name is AR KuraKura Sumatra and the URL address https://play.google.com/store/apps/details?id=com.mac.kurakura.

We implemented a One Group Pretest Posttest Design, where a group of students went through a pretest, then received treatment using turtle mobile learning, and were later given a posttest. We also employed both quantitative and qualitative methods in this research to provide a holistic view about the scientific literacy problem and the effectiveness of turtle mobile learning without any manipulation in the classroom (Creswell, 2012). Interviews were held to support research findings from the pretest and posttest results. The research design is in Table 1.

Table-1. One group pretest posttest design

\begin{tabular}{|c|c|c|}
\hline \multicolumn{3}{|l|}{ Treatment group } \\
\hline O1 & $\mathbf{X}$ & $\mathbf{O 2}$ \\
\hline $\begin{array}{l}\text { Pretest: Turtle and Scientific } \\
\text { Literacy }\end{array}$ & $\begin{array}{l}\text { Treatment: Problem Solving Activity } \\
\text { Using Turtle Mobile Learning } \\
\text { Application }\end{array}$ & $\begin{array}{l}\text { Posttest: Turtle and Scientific } \\
\text { Literacy }\end{array}$ \\
\hline
\end{tabular}

The application feasibility testing involved 20 students who never had any lessons about the Sumatra turtle. The students involved were from grades 4 and 5 in elementary school-aged between 10 and 12 years. The research was conducted at State Elementary School Number 34 in Bengkulu city, Indonesia, from March to May 2018.

The data obtained through the research instrument was analyzed using IBM SPSS Statistics 22. Firstly, it needed to make sure that the data was distributed normally and homogeneously. By using mean scores, gain scores were calculated. T-test analysis was applied to see the differences in scores between pre and post-test. The T-test was used for a parametric test if the data formed a normal distribution. Paired Samples T-test were applied in this study, and each individual in the sample was measured two times in pre and post-test. Both data were used to make comparative measurements (Field, 2009).

The pretest was carried out in the first week of the research, while the post-test was carried out at the end. The effectiveness of turtle mobile learning was measured by the students' learning results from both pretest and posttest. The calculation of test results in this study used Equation 1.

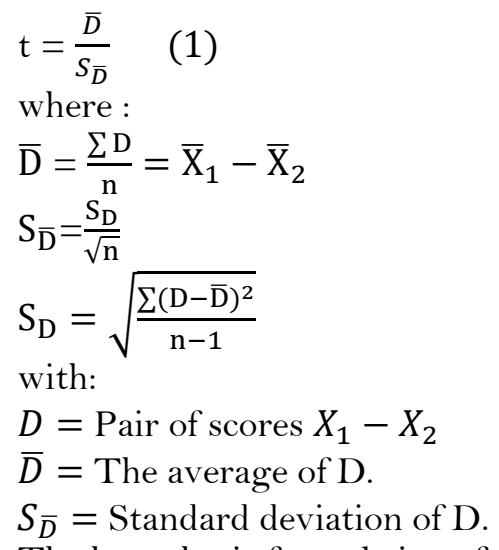

The hypothesis formula is as follows:

$H_{0}=$ There is no effect of turtle mobile learning on the student understanding of turtle conservation.

$H_{1}=$ There is an effect of turtle mobile learning on the student understanding of turtle conservation.

By hypothesis criteria:

The null hypothesis will receive $-t_{\left(1-1 / 2^{\alpha}\right)}<t<t_{\left(1-1 / 2^{\alpha}\right.}$, the value $t_{\left(1-1 / 2^{\alpha)}\right.}$ is obtained from the distribution list with a chance $(1-1 / 2 \propto)$, otherwise null hypothesis is rejected.

Any improvement in each aspect of students' learning independence and conceptual understanding descriptively obtained with the normalized gain score as a basis. N-gain test was conducted to determine the growth of students' scientific literacy after being taught using turtle mobile learning. The gain score calculation was done by using the following gain Equation 2 according to Hake (2002). 
Where:

$$
g=\frac{S_{\text {post }}-S_{\text {pre }}}{S_{\text {max }}-S_{\text {pre }}}
$$

$$
\begin{aligned}
& g=N-\text { gain } \\
& S_{\text {post }}=\text { Posttest score } \\
& S_{\text {pre }}=\text { Poretest score } \\
& S_{\text {maxs }}=\text { Maximum score }
\end{aligned}
$$

The interpretation of the gain in each aspect observed could be done with the gain score criteria according to Hake (1998) as a basis, shown in Table 2.

Table-2. Criteria for N-gain score

\begin{tabular}{c|c|c}
\hline \multicolumn{3}{|c}{ Table-2. Criteria for N-gain score } \\
\hline No & Gain Score & Criteria \\
\hline 1 & $\mathrm{~g} \geq 0.7$ & High \\
\hline 2 & $0.3 \leq \mathrm{g}<0.7$ & Medium \\
\hline 3 & $\mathrm{~g}<0.3$ & Low \\
\hline
\end{tabular}

The research was finished by performing interviews with five students from each researched class. The purpose of the interview was to get the data not recorded from the test result. The question from the interview was about the advantages and new things that students received from the turtle mobile learning process. Therefore, the interview result may endow further understanding of the test results which is needed to enrich the post-research discussion.

\section{Results and Discussion}

Mobile technology enhances to speed of access to information, wherever and whenever, and may be deployed on a variety of platforms. In Figure 1 is the interface of the turtle mobile application.
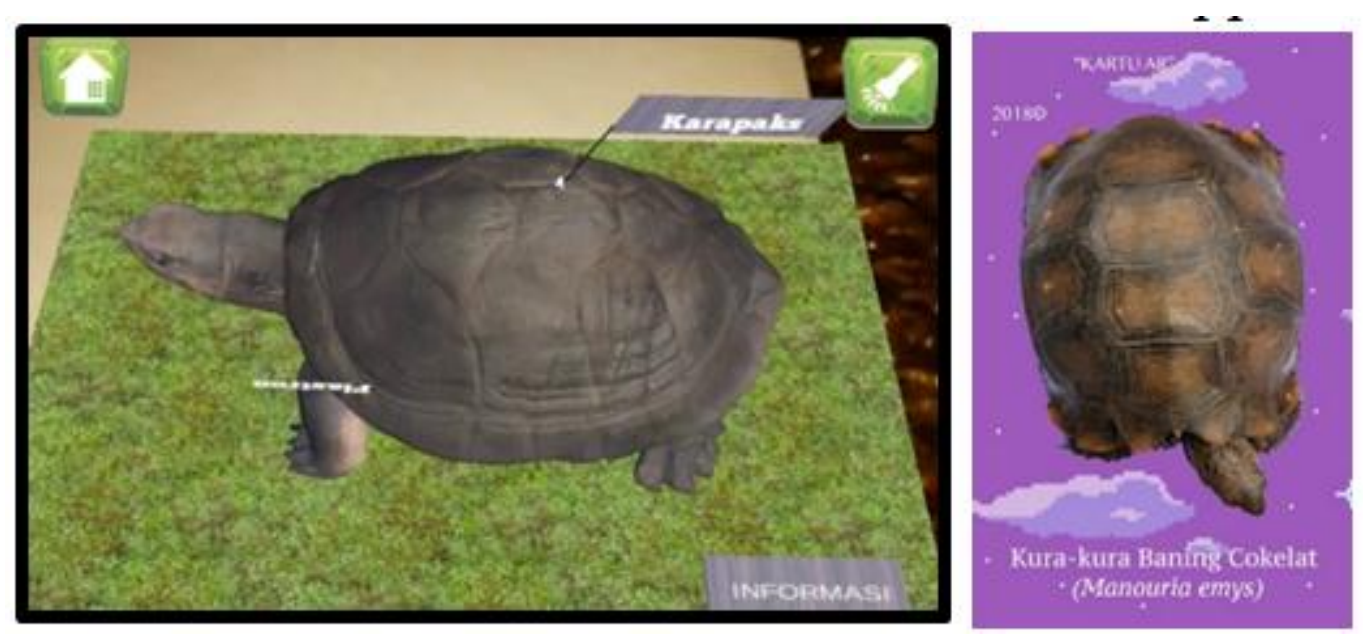

Source: Research data

Figure-1. Interface turtle mobile learning.

-kura Baning Cokelat

students to discover the concept of conservation. The application made the learning atmosphere more interactive and active as shown in Figure 2.
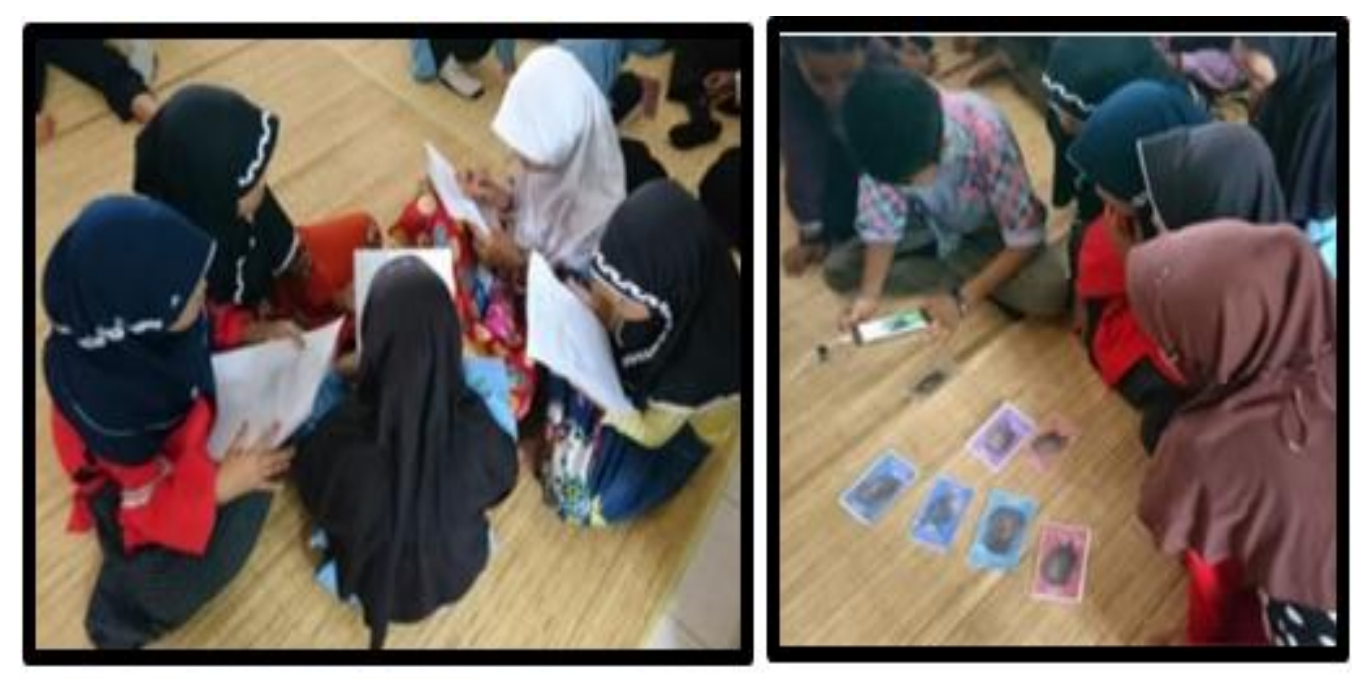

Source: Research data.

Figure-2. Learning activity with turtle mobile learning.

The testing treatment in this study was to run/play turtle mobile learning. The pretest was given before the class received the treatments with turtle mobile learning to explore students' prior knowledge. Pretest and posttest data are presented in Table 3. 


\begin{tabular}{c|c|c|c|c|c}
\hline \multicolumn{7}{c}{ Table-3. Pretest and posttest results. } \\
\hline NO & Pretest $\left(\mathbf{X}_{1}\right)$ & Posttest $\left(\mathbf{X}_{2}\right)$ & $\mathbf{D}$ & $\mathbf{D}-\overline{\boldsymbol{D}}$ & $(\mathbf{D}-\overline{\mathbf{D}})^{2}$ \\
\hline 1 & 50 & 66,7 & $-16,7$ & 35,46 & 1257,4 \\
\hline 2 & 50 & 100 & -50 & 2,16 & 4,66 \\
\hline 3 & 16,7 & 100 & $-83,3$ & $-31,14$ & 969,69 \\
\hline 4 & 33,3 & 83 & $-49,7$ & 2,46 & 6,05 \\
\hline 5 & 33,3 & 100 & $-77,7$ & $-25,54$ & 652,29 \\
\hline 6 & 33,3 & 100 & $-77,7$ & $-25,54$ & 652,29 \\
\hline 7 & 33,3 & 100 & $-77,7$ & $-25,54$ & 652,29 \\
\hline 8 & 16,7 & 100 & $-83,3$ & $-31,14$ & 969,69 \\
\hline 9 & 66,7 & 100 & $-33,3$ & 18,76 & 355,69 \\
\hline 10 & 50 & 66,7 & $-16,7$ & 35,46 & 1257,4 \\
\hline 11 & 50 & 66,7 & $-16,7$ & 35,46 & 1257,4 \\
\hline 12 & 33,3 & 66,7 & $-33,4$ & 18,76 & 351,93 \\
\hline 13 & 50 & 66,7 & $-16,7$ & 35,46 & 1257,4 \\
\hline 14 & 50 & 66,7 & $-16,7$ & 35,46 & 1257,4 \\
\hline 15 & 33,3 & 83 & $-49,7$ & 2,46 & 6,05 \\
\hline 16 & 33,3 & 100 & $-77,7$ & $-25,54$ & 652,29 \\
\hline 17 & 50 & 100 & -50 & 2,16 & 4,66 \\
\hline 18 & 16,7 & 100 & $-83,3$ & $-31,14$ & 969,69 \\
\hline 19 & 16,7 & 100 & $-83,3$ & $-31,14$ & 969,69 \\
\hline 20 & 33,3 & 83 & $-49,7$ & 2,46 & 6,05 \\
\hline Total & 749,9 & $1.749,2$ & $-1043,3$ & $-0,1$ & $13.510,1$ \\
\hline
\end{tabular}

Source: Research data.

From the data in Table 3 the following calculations are obtained:

$\sum D=-1043 \quad \bar{D}=\frac{-1043,3}{20}=-52.16$

$\bar{X}_{1}=\frac{749,9}{20}=37.49 \bar{X}_{2}=\frac{2910}{30}=97$

$S_{D}=\sqrt{\frac{\sum(D-\bar{D})^{2}}{n-1}}$

$S_{D}=\sqrt{\frac{13510,1}{19}}=\sqrt{308,16}=26,66$

$S_{\bar{D}}=\frac{S_{D}}{\sqrt{n}}=\frac{26,66}{\sqrt{30}}=\frac{26,66}{5,47}=4,87$

Then, t calculation

$t=\frac{\bar{D}}{S_{\bar{D}}}$

$t=\frac{-52,16}{4,87}=-10,71$

It is known that significance level $\alpha$ at 0.05 then $\left.t_{1-1 / 2} \propto\right)=t_{(0.975)}$ and $d k=n_{1}+n_{2}-2$

Where:

$\mathrm{n}_{1}=$ number of pretest respondents.

$\mathrm{n}_{2}=$ number of posttest respondents.

then $\mathrm{dk}=20+20-2=38$.

After obtaining the value $\mathrm{dk}$, we can find the value of $t$ table in the $t$ distribution list for a two-sided test. Price $\mathrm{t}$ $(0.975)$ for the two-sided test on student distribution $(\mathrm{t}) \mathrm{d}_{\mathrm{k}}=38$ is obtained $t$-table $=2.024$ from the calculation result $t=-10.71$ is in the area of rejecting $\mathrm{H}_{\mathrm{o}}$. It is concluded that there is an influence on aspects of student understanding about Sumatran turtles.

Quantitative data analysis aims to determine the effectiveness of turtle mobile learning to improve student science literacy about turtle conservation using the $\mathrm{N}$-gain test.

$$
g=\frac{S_{\text {post }}-S_{\text {pre }}}{S_{\text {max }}-S_{\text {pre }}}=\frac{87.46-37.49}{100-37.49}=\frac{49.97}{62.51}=0.8
$$

Table 3 shows comparative results from the testing of students' conceptual understanding of the turtle during pretest and posttest. Based on the results in the tables and calculations, it shows that the turtle mobile learning technology as a scientific literacy source could improve students' understanding (NEPS, 2016). The result of Ngain calculation analysis $=0.8$, indicating that this application has high effectiveness in improving the scientific literacy of elementary school students. This application has provided information on each species of turtle, an explanation of each part of the turtle's body, and an encyclopedia of turtles. It is also equipped with a quiz to evaluate the student's conceptual understanding.

The user response test for the Android-based Sumatran Tortoise Augmented Reality Application was carried out to assess the suitability between the applications with the students as respondents and using students' responses about the application. The distribution of students response questionnaires were divided into four indicators: (1) like to learn with mobile application; (2) easy to understand the Sumatran turtle type with augmented reality technology; (3) the augmented reality technology made the learning process more interesting; and (4) it is easy to understand the shape of a Sumatran Turtle. Students filled the student response questionnaires by selecting one answer from the "agree, disagree" in the answer category. The data obtained is in Table 4. 
Table-4. Student response tes

\begin{tabular}{|c|c|c|c|}
\hline No & Response & Disagree & Agree \\
\hline 1. & $\begin{array}{l}\text { I don't like learning about the type of Sumatran turtle using the Augmented } \\
\text { Reality application of the Sumatran turtle }\end{array}$ & $85 \%$ & $15 \%$ \\
\hline 2. & $\begin{array}{l}\text { After seeing the Augmented Reality application of Sumatran turtles, I easily } \\
\text { understand about the Sumatran turtle }\end{array}$ & $\mathrm{O} \%$ & $100 \%$ \\
\hline 3. & $\begin{array}{l}\text { After using the Augmented Reality application of this turtle, I am not interested in } \\
\text { understanding about the Sumatran turtle type }\end{array}$ & $100 \%$ & $\mathrm{O} \%$ \\
\hline 4. & $\begin{array}{l}\text { This turtle Augmented Reality application makes it easy for me to understand the } \\
\text { shape of the Sumatran turtle }\end{array}$ & $0 \%$ & $100 \%$ \\
\hline 5. & I easily understand and remember the turtle after using the turtle mobile learning & $\mathrm{O} \%$ & $100 \%$ \\
\hline
\end{tabular}

From Table 4, it is apparent that students liked to learn about Sumatran turtle using turtle mobile learning applications. Positive responses were over 80 percent. In this study, the researcher took on the role as a teacher to implement the learning while the real teacher took part as an observer. After observing the learning, the teacher stated that interactive learning using augmented reality media was very useful for students because many do not currently know that the Sumatran turtles is threatened with extinction. However, to bring tortoise objects directly to class is not possible because special treatment is needed to bring the original turtle to class in front of students. With this application, students can see turtle objects that closely resemble the original in 3-dimensional shapes. The teacher was very impressed because the students became excited, creative, and inquisitive. The utilization of Android media can improve student scientific literacy because flexible android media can be used repeatedly, anytime and anywhere. Based on the discussion, the test results can be used as an input for teachers to improve the learning process and the quality of scientific literacy.

\section{Conclusion}

Turtle mobile learning is a scientific literacy source developed for use on Android smartphones. The application is intended be used by elementary school students both within and outside of the classroom. The application is equipped with information on each species of turtle, an explanation of turtle's body, an encyclopedia of turtles, and a quiz. The students could understand the lesson easily because they saw the tortoise directly in 3D. Augmented reality provides students with convenience in building concepts because it can simplify visualization which is complex into that which is easy to understand. The data was divided into pretest and posttest to measure the students' conceptual understanding. The pretest was the conceptual understanding test given before students used the Turtle mobile learning application, while the posttest was the conceptual understanding test given afterwards. Based on the test results, this application can improve students' understanding of turtle conservation, and has application across many countries by means of its availability through the Google Play store.

\section{References}

Aikenhead, G.S., 1990. Scientific/technological literacy, critical reasoning and classroom practice. In S. P. Norris, \& L. M. Phillips (Eds.), Foundations of literacy policy in Canada. Calgary: Detselig Enterprises. pp: 127-145.

Ambusaidi, A., A.A. Musawi, S. Al-Balushi and K. Al-Balushi, 2018. The impact of virtual lab learning experiences on 9th grade students' achievement and their attitudes towards science and learning by virtual lab. Journal of Turkish Science Education (TUSED), 15(2).

Bappenas, 2016. Indonesia biodiversity strategy and action plan 2015-2020. Jakarta: Ministry of National Development Planning.

Campbell, D.T. and J.C. Stanley, 1999. Experimental and quasi-experimental design for research. Chicago: Rand McNally \& Company.

Cibir, A. and M. Ozden, 2017. Elementary school students' attitudes towards science: Kutahya sample. Journal of Educational Sciences Research, 7(2): 27-43.

Creswell, J.W., 2012. Educational research: Planning, conducting, and evaluating quantitative and qualitative. 4th Edn., United States of America: Pearson Education.

Field, A., 2009. . Discovering statistics using SPSS 3rd (ed). London: SAGE Publications Ltd.

Hake, R.R., 1998. Interactive-engagement versus traditional methods: A six-thousand-student survey of mechanics test data for introductory physics courses. American Journal of Physics, 66(1): 64-74.Available at: https://doi.org/10.11 19/1.18809.

Hake, R.R., 2002. Relationship of individual student normalized learning gains in mechanics with gender, high-school physics, and pretest scores on mathematics and spatial visualization. Paper Presented at the Physic Education Research Conference, Boise, ID.

Hodson, D., 2003. Time for action: Science education for an alternative future. International Journal of Science Education, 25(6): 645-670.

Liliarti, N. and H. Kuswanto, 2018. Improving the competence of diagrammatic and argumentative representation in physics through android-based mobile learning application. International Journal of Instruction, 11(3): 107-122.Available at: https://doi.org/10.12973/iji.2018.1138a.

Nesmith, S., E. Ditmore, L. Scott and T. Zhu, 2017. " This is more about a book than about science!" Preservice teachers' perceptions toward using literacy strategies in inquiry-based science lessons. Electronic Journal of Science Education, 21(5): 1-13.

OECD, 2013. Draft science framework. Available from http://www.oecd.org/pisa/pisaproducts/DraftPISA2015ScienceFramework.pdf.

Organization for Economic Co-operation and Development (OECD), 2015. Country Note: Indonesia, programme for international student assessment (PISA) results from PISA 2015. Available from https://www.oecd.org/pisa/PISA-2015-Indonesia.pdf.

Rusilowati, A., S. Nugroho and S. Susilowati, 2016. Development of science textbook based on scientific literacy for secondary school. Indonesian Journal of Physical Education, 12(2): 98-105.Available at: https://doi.org/10.15294/jpfi.v 12i2.4252.

Spante, M., S.S. Hashemi, M. Lundin and A. Algers, 2018. Digital competence and digital literacy in higher education research: Systematic review of concept use. Cogent Education, 5(1): 1519143.

Subali, B., K. Kumaidi, N. Aminah and B. Sumintono, 2019. Student achievement based on the use of scientific method in the natural science subject in elementary school. Jurnal Pendidikan IPA Indonesia, 8(1): 39-51.Available at: https://doi.org/10.15294/jpii.v8i1.16010.

Wijayanti, A. and M. Basyar, 2016. The development of thematic-integrated e-portfolio media web blog based to increase the scientific literacy of elementary teacher education program's student. Jurnal Pendidikan IPA Indonesia, 5(2): 284-290.

Winarni, E.W. and E.P. Purwandari, 2018. Disaster risk reduction for earthquake using mobile learning application to improve the students understanding in elementary school. Mediterranean Journal of Social Sciences, 9(2): 205-214.Available at: https://doi.org/10.2478/mjss-2018-0040. 